\title{
Whole blood thrombin generation in Bmal1-deficient mice
}

Citation for published version (APA):

Ninivaggi, M., Kelchtermans, H., Kuijpers, M. J., Hemmeryckx, B., Heemskerk, J. W. M., Lindhout, T., Hoylaerts, M. F., \& de Laat, B. (2014). Whole blood thrombin generation in Bmal1-deficient mice.

Thrombosis and Haemostasis, 112(2), 271-275. https://doi.org/10.1160/TH13-11-0910

Document status and date:

Published: 01/08/2014

DOI:

10.1160/TH13-11-0910

Document Version:

Publisher's PDF, also known as Version of record

Document license:

Taverne

\section{Please check the document version of this publication:}

- A submitted manuscript is the version of the article upon submission and before peer-review. There can be important differences between the submitted version and the official published version of record.

People interested in the research are advised to contact the author for the final version of the publication, or visit the DOI to the publisher's website.

- The final author version and the galley proof are versions of the publication after peer review.

- The final published version features the final layout of the paper including the volume, issue and page numbers.

Link to publication

\footnotetext{
General rights rights.

- You may freely distribute the URL identifying the publication in the public portal. please follow below link for the End User Agreement:

www.umlib.nl/taverne-license

Take down policy

If you believe that this document breaches copyright please contact us at:

repository@maastrichtuniversity.nl

providing details and we will investigate your claim.
}

Copyright and moral rights for the publications made accessible in the public portal are retained by the authors and/or other copyright owners and it is a condition of accessing publications that users recognise and abide by the legal requirements associated with these

- Users may download and print one copy of any publication from the public portal for the purpose of private study or research.

- You may not further distribute the material or use it for any profit-making activity or commercial gain

If the publication is distributed under the terms of Article $25 \mathrm{fa}$ of the Dutch Copyright Act, indicated by the "Taverne" license above, 


\title{
Whole blood thrombin generation in Bmal1-deficient mice
}

\author{
Marisa Ninivaggi'; Hilde Kelchtermans'; Marijke J. Kuijpers'; Bianca Hemmeryckx³; Johan W. M. Heemskerk²; Theo Lindhout'; \\ Marc F. Hoylaerts ${ }^{3}$; Bas de Laat ${ }^{1,2}$ \\ ${ }^{1}$ Synapse BV, CARIM, Maastricht University Medical Centre, Maastricht, The Netherlands; ${ }^{2}$ Biochemistry, CARIM, Maastricht University Medical Centre, Maastricht, The Netherlands; \\ ${ }^{3}$ Center for Molecular and Vascular Biology, KU Leuven, Leuven, Belgium
}

\begin{abstract}
Summary
The Calibrated Automated Thrombogram (CAT) assay that measures thrombin generation (TG) in platelet-poor and -rich plasma, is increasingly being recognised as a more sensitive tool to determine the overall function of the haemostatic system. We developed a method enabling the measurement of TG in a small aliquot of blood. The objective was to validate this assay in mouse blood and to examine the rate and extent of TG in a mouse model of premature aging. TG was assayed in blood from 20- to 28-week-old brain and muscle ARNT-like protein-1 (Bmal1)-deficient (knockout, KO) mice and wild-type (WT) littermates. Bmal1-KO mice are known to display symptoms of premature aging. TG was initiated by adding calcium, tissue factor and a thrombin specific substrate. After TG, the samples were prepared for scanning electron microscopy (SEM). The intra-assay variations (\%) in
\end{abstract}

mouse blood of the endogenous thrombin potential (ETP), peak height, lag time, time-to-peak and velocity index were $10 \%$ or less $(n=24)$. We found that Bmal1-KO mice have a significantly $(p<0.001)$ higher ETP (437 $\pm 7 \mathrm{nM}$.min; mean $\pm \mathrm{SD}, \mathrm{n}=7$ ) when compared with WT mice ( $E T P=220 \pm 45 \mathrm{nM}$.min; mean $\pm S D, n=5)$. The peak heights also differed significantly $(p=0.027)$. By applying SEM we found that Bmal1 deficient mice display a denser fibrin network with smaller pores compared to WT mice. In conclusion, the whole blood TG assay in mice revealed to be reproducible. As a proof-of-principle we have shown that the whole blood TG assay is capable of detecting a prothrombotic phenotype in Bmal1-KO mice.

\section{Keywords}

Thrombin generation, Bmal1-KO mice, aging

Financial support:

This project was funded by an unrestricted grant from Center for Translational Molecular Medicine (CTMM) and the Dutch Hart Foundation (NHS 2006T053).

Received: November 5, 2013

Accepted after major revision: March 12, 2014

Epub ahead of print: April 17, 2014

http://dx.doi.org/10.1160/TH13-11-0910

Thromb Haemost 2014; 112: 271-275

\section{Introduction}

In the research field of thrombosis and haemostasis, the use of mouse models to investigate human coagulation disorders is getting increasingly popular (1-5). Plasma coagulation tests like the activated partial thromboplastin time (aPTT) and the prothrombin time (PT) are performed on regular basis. However, it has been demonstrated that these tests lack the sensitivity to detect conditions of hypo- and especially hypercoagulability (6-9). The Calibrated Automated Thrombogram (CAT) assay that measures thrombin generation (TG) in platelet-poor and platelet-rich plas$\mathrm{ma}$, is increasingly being recognised as a more sensitive tool to determine the overall function of the haemostatic system (10-14). Tchaikovski et al. (4) adapted this assay to measure TG in mouse plasma enabling the demonstration of factor (F)V Leiden-, oral contraception- and pregnancy-induced hypercoagulability. In addition, the plasma tests require relatively large amounts of mouse blood and do not account for the presence of blood cells.

Until recently, it was not possible to measure TG in whole blood due to technical problems that lead to highly erratic signals related to quenching of the fluorescent signal and red blood cell sedimentation and retraction $(15,16)$. We recently developed a method in which these problems were overcome enabling the measurement of TG in a small aliquot of blood. The advantage of the use of this whole blood CAT (WB-CAT) assay is that it enables us to include the effect of blood cells on TG, thereby getting one step closer to physiological conditions compared to plasma. A more practical advantage is that it omits centrifugation steps, thereby also reducing the time needed to perform the assay and the experimental errors that can occur. We recently published the technical validation of this WB-CAT assay demonstrating its utility $(17,18)$. An additional advantage of the WB-CAT is the small sample volume necessary to perform the assay (less than $100 \mu \mathrm{l}$ ), rendering it needless to sacrifice the mice.

In this paper we have studied the prothrombotic phenotype in Brain and muscle ARNT-like protein-1 (Bmal1) clock gene knockout (KO) compared to wild-type (WT) mice using our WB-CAT assay. The Bmal1-KO mice have an impaired circadian behaviour and demonstrate loss of rhythmicity in the expression of their clock genes. They are known to have a reduced lifespan and display symptoms of premature aging (19-21). Plasma clotting assays revealed a discrepancy in test results. Fibrinogen levels and FVII 
activity were increased and PT was decreased in Bmall-KO mice, while the aPTT was prolonged $(19,22,23)$.

The goal of this study was to demonstrate that the WB-CAT assay can also be applied on mouse blood. As a proof-of-principle we have shown that the WB-CAT assay is capable of detecting a prothrombotic phenotype in Bmal1-KO mice.

\section{Materials and methods}

\section{Mice}

For the first methodical part of the study, whole blood was taken from C57Bl/6 mice (Charles River, Sulzfeld, Germany) to validate the WB-CAT assay $(n=6)$. For the second part of our study, male Bmal1-KO mice and WT littermates were generated in the animal facility of the Centre for Molecular and Vascular Biology (KU Leuven, Leuven, Belgium) as previously described (23). Their age varied between 22 and 28 weeks $(n=12)$. All animals were kept in 12-hour night/day temperature controlled cages and had free access to drinking water and standard chow (KM-04-k12, Muracon, Carfil, Oud-Turnhout, Belgium; 13\% kcal as fat, caloric value 10.9 $\mathrm{kJ} / \mathrm{g}$ ) ad libitum. All animal procedures were approved by the Ethical Committees of the KU Leuven or Maastricht University and performed in accordance with the National Institutes of Health Guide for the Care and Use of Laboratory Animals (1996) (23).

\section{Blood sampling}

Mice were anaesthetised with subcutaneous injection of ketamine and xylazine $(0.1 \mathrm{mg} / \mathrm{g}$ and $0.02 \mathrm{mg} / \mathrm{g}$ body weight). Subsequently, blood was taken via retro-orbital puncture using a glass capillary with a length of $2 \mathrm{~cm}$ that was filled with sodium citrate $(3.8 \%)$. The first three drops of citrate/blood were discarded. The following drops were collected on $3.8 \%$ sodium citrate ( $1 / 10$ volume) in a $0.5 \mathrm{ml}$ Eppendorf tube and mixed immediately to prevent clotting. The red blood cell and platelet count were measured using a Cell-

Table 1: Tissue factor dependency of thrombin generation parameters in C57BI/6 mice.

\begin{tabular}{|l|l|l|l|l|l}
\hline & ETP & Peak & Lagtime & TTP & VI \\
\hline & $\left(\mathrm{nM}^{*} \min \right)$ & $(\mathrm{nM})$ & $(\min )$ & $(\min )$ & (nM/min) \\
\hline 0 pM TF & $310 \pm 26$ & $24 \pm 0.4$ & $5.7 \pm 0.1$ & $10.6 \pm 0.1$ & $4.9 \pm 0.2$ \\
\hline 0 pM TF + CTI & $339 \pm 14$ & $22 \pm 0.7$ & $7.8 \pm 1.6$ & $13.3 \pm 2.0$ & $40 \pm 0.4$ \\
\hline $\mathbf{0 . 2 5}$ pM TF & $284 \pm 26$ & $30 \pm 2.5$ & $4.3 \pm 0.3$ & $7.4 \pm 0.3$ & $9.8 \pm 0.9$ \\
\hline $\mathbf{0 . 5}$ pM TF & $285 \pm 12$ & $44 \pm 4.3$ & $3.0 \pm 0.2$ & $5.3 \pm 0.3$ & $19 \pm 2.5$ \\
\hline 1 pM TF & $320 \pm 11$ & $55 \pm 3.1$ & $2.2 \pm 0.1$ & $4.2 \pm 0.1$ & $27 \pm 2.0$ \\
\hline 2 pM TF & $345 \pm 14$ & $68 \pm 7.4$ & $1.5 \pm 0.1$ & $3.2 \pm 0.1$ & $42 \pm 8.5$ \\
\hline 2.5 pM TF & $332 \pm 16$ & $80 \pm 2.1$ & $1.1 \pm 0.1$ & $2.7 \pm 0.1$ & $52 \pm 2.6$ \\
\hline
\end{tabular}

Data represent the mean $\pm \mathrm{SD}(\mathrm{N}=3)$; $\mathrm{TF}$, tissue factor; $\mathrm{CTI}$, corn trypsin inhibitor; ETP, endogenous thrombin potential; TTP, time-to-peak; VI, velocity index.
Dyn 3200R counter (Abbott Diagnostics, Louvain-La-Neuve, Belgium).

\section{Whole blood thrombin generation}

Whole blood TG was performed in a 96-well plate as previously described (17). Briefly, the total volume of blood needed for TG and calibration measurement in triplicate is $60 \mu \mathrm{l}$. For TG measurement, $30 \mu \mathrm{l}$ of citrated whole blood was mixed with $10 \mu \mathrm{l}$ thrombin specific substrate (P2Rho;1.8 mM) and activated with 20 $\mu \mathrm{TF}$ and $\mathrm{CaCl} 2$ (1.5 pM and $50 \mathrm{mM}$, respectively). For the calibration measurement we mixed $30 \mu \mathrm{l}$ of citrated whole blood with $10 \mu \mathrm{l}$ thrombin specific substrate (P2Rho;1.8 mM) and $20 \mu \mathrm{l}$ a2M-thrombin (300 nM thrombin activity). Hirudine (50 nM) was also added to the calibrator wells in order to prevent thrombin formation that could affect the linearity of the calibration curve. Immediately after activation, $5 \mu \mathrm{l}$ of the mixture was added to the wells containing the porous filter paper discs and the wells were covered with $40 \mu \mathrm{l}$ of mineral oil (USB Corporation) to prevent evaporation. Samples were run for 50 minutes (min) and fluorescence was recorded every 5 seconds with a Fluoroskan Ascent microplate fluorometer with $\lambda \mathrm{ex}=485 \mathrm{~nm}$ and $\lambda \mathrm{em}=538 \mathrm{~nm}$ (Thermolabsystems, Helsinki, Finland). All procedures were performed at $37^{\circ} \mathrm{C}$.

\section{Scanning electron microscopy}

Following TG, the filter paper disks were fixated with gluteraldehyde, dehydrated with ethanol/HMDS and coated with gold using a Rotary-Pumped Sputter Carbon Coater (Quorum Technologies, East Grinstead, West Sussex, UK). Samples were analysed using a Phenom G2 pro desktop scanning electron microscopy (SEM, Phenom World, Eindhoven, The Netherlands).

\section{Statistical analysis}

The Mann-Whitney $U$ test was used for statistical analysis of the data using SPSS 19.0 for windows (SPSS, Chicago, IL, USA). A p-value below 0.05 was considered to be significant.

\section{Results TF dependency}

TG was measured in mouse blood that was activated with various TF concentrations in the presence of P2Rho $(300 \mu \mathrm{M})$ and $\mathrm{CaCl}_{2}$ $(16.7 \mathrm{mM})$. The values of the thrombogram parameters are depicted in $>$ Table 1. Substantial thrombin generation was already seen in the condition without TF, possibly resulting from the presence of endogenous TF or contact activation. However, addition of CTI $(50 \mu \mathrm{g} / \mathrm{ml})$ to the blood collection tube partly reduced contact activation as indicated by a minor prolongation of the lag time (5.7 vs $7.8 \mathrm{~min}$ ) and time-to-peak (10.6 vs $13.3 \mathrm{~min}$ ) without affecting the other parameters. When the same experiment was performed with mouse plasma, CTI $(50 \mu \mathrm{g} / \mathrm{ml})$ completely diminished 
Table 2: Intra-assay variation of whole blood thrombin generation in a C57BI/6 mouse.

\begin{tabular}{l|l|l|l}
\hline & Mean & SD & CV \\
\hline ETP (nM*min) & 309.7 & 37.1 & 12.0 \\
\hline Peak (nM) & & & \\
\hline Lagtime (min) & 40.3 & 3.1 & 7.6 \\
\hline TTP (min) & 2.6 & 0.2 & 7.4 \\
\hline VI (nM/min) & 5.0 & 0.3 & 6.2 \\
\hline
\end{tabular}

Blood was activated with $0.5 \mathrm{pM}$ TF and $16.7 \mathrm{mM} \mathrm{CaCl}_{2}$. SD, standard deviation; CV, coefficient of variation; ETP, endogenous thrombin potential; TTP, time-topeak; VI, velocity index; The sample was tested 24 times in one single run.

thrombin generation. Moreover, in the absence of exogenous TF, thrombin generation was neither observed. These findings indicate that the presence of blood cells diminishes the inhibitory effect of CTI and that the resulting TG is likely not due to the presence of endogenous TF. With increasing TF concentrations, a dose-dependent increase in peak height and decrease in lag time and time-to-peak was observed. The ETP was not dependent on the TF concentration in this assay.

\section{Precision of the WB-CAT assay in mouse blood}

The intra-assay variation of the WB-CAT assay was tested for 24 replicates. Blood was taken from three different WT mice and activated with $0.5 \mathrm{pM} \mathrm{TF}, 300 \mu \mathrm{M} \mathrm{P}{ }_{2}$ Rho and $16.7 \mathrm{mM} \mathrm{CaCl}_{2}$. The mean intra-assay variation of the ETP, peak height, lag time, timeto-peak and velocity index from one representative mouse are shown in $>$ Table 2. Except for the ETP, all the parameters have an acceptable coefficient of variation ( $\mathrm{CV} \leq 10 \%)$.

\section{Comparing TG in Bmal1-KO and WT mice}

TG was measured in blood of WT and KO mice in the presence of $300 \mu \mathrm{M} \mathrm{P}_{2} \mathrm{Rho}, 0.5 \mathrm{pM} \mathrm{TF}$ and $16.7 \mathrm{mM} \mathrm{CaCl}_{2}$. The mean age of the WT and KO mice was 24.2 and 25.2 weeks, respectively $(\mathrm{p}=0.48)$. $\triangleright$ Figure 1 shows the mean TG curve of the WT group (black line) and the $\mathrm{KO}$ group (interrupted line). The mean values of the TG parameters for each group are depicted in Table 3 . The lag time, time-to-peak and velocity index did not differ significantly between the two groups (p-values were $0.45,0.145$ and 0.742 respectively). However, significant higher TG peak height (30.1 nM vs $45.8 \mathrm{nM} ; \mathrm{p}=0.027)$ and ETP ( $220 \mathrm{nM}$.min vs 437.6 nM.min; $\mathrm{p}<0.001$ ) values were found in the KO mice. The higher $\mathrm{TG}$ in the KO mice correlates with the prothrombotic phenotype seen in these mice. Red blood cell count was found to be significantly $(\mathrm{p}<0.001)$ higher in the KO mice $\left(9914 \times 10^{3} / \mu \mathrm{l} \pm 724 \times 10^{3} / \mu \mathrm{l}\right)$ compared to WT mice $\left(7900 \times 10^{3} / \mu \mathrm{l} \pm 334 \times 10^{3} / \mu \mathrm{l}\right)$. Also the platelet count of KO mice was significantly $(\mathrm{p}<0.005)$ higher $\left(1281 \times 10^{3} / \mu \mathrm{l} \pm 157 \times 10^{3} / \mu \mathrm{l}\right)$ compared to that of WT mice $\left.942 \times 10^{3} / \mu \mathrm{l} \pm 152 \times 10^{3} / \mu \mathrm{l}\right)$.

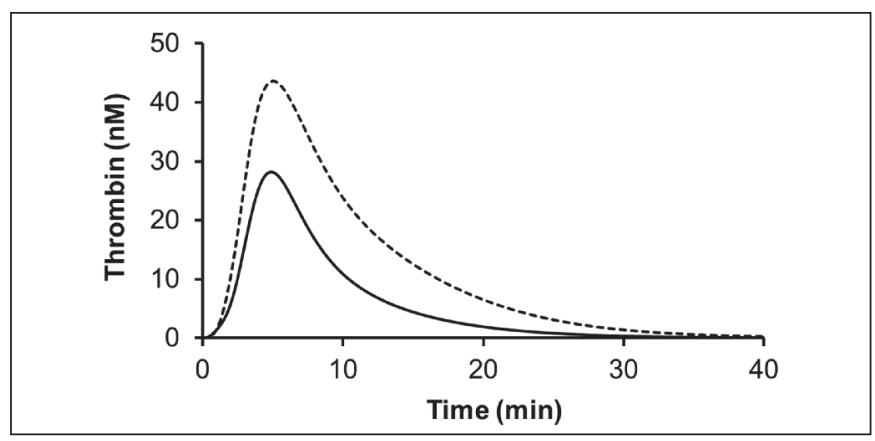

Figure 1: Representative TG curves of Bmal1-KO and WT mice. Samples were activated with $0.5 \mathrm{pM}$ TF and $16.7 \mathrm{mM}$ calcium. The full and interrupted lines represent the WT and KO mice, respectively. Both curves are the mean of three measurements.

\section{Visualisation of fibrin network}

At the end of the TG assay, the samples were fixated and analysed by scanning electron microscopy. Representative images are shown in Figure 2 (5000x magnification). The images in the upper part are clots from WT mice, while images of the lower part represent those from the KO mice. While the fibrin structure in WT clots is more localised, the fibrin formation is seen throughout the whole paper matrix in $\mathrm{KO}$ clots. In addition, much more fibrin is present in clots of KO versus WT mice.

\section{Discussion}

It is becoming increasingly apparent that global blood clotting tests like thrombin generation assays are more sensitive to detect conditions of hypo- and especially hypercoagulability when compared to conventional assays only measuring clotting times. Since transgenic mouse models have been very helpful in increasing our insights in the process of blood coagulation, it is appropriate to develop a method by which TG can be measured in mouse blood.

Table 3: Whole blood thrombin generation parameters in Bmal1-KO and WT mice.

\begin{tabular}{|l|l|l|l|l|l|}
\hline & $\begin{array}{l}\text { WT } \\
(\mathbf{n}=5)\end{array}$ & & $\begin{array}{l}\text { KO } \\
(\mathbf{n = 7})\end{array}$ & & \\
\hline & Mean & SD & Mean & SD & P-value \\
\hline ETP (nM*min) & 220.3 & 45.1 & 437.6 & 78.3 & $<0.001$ \\
\hline Peak (nM) & 30.1 & 3.7 & 45.8 & 14.3 & 0.027 \\
\hline Lagtime (min) & 2.5 & 0.8 & 2.2 & 0.5 & 0.45 \\
\hline TTP (min) & 4.8 & 0.9 & 5.9 & 1.6 & 0.145 \\
\hline VI (nM/min) & 13.7 & 3.3 & 15.0 & 9.6 & 0.742 \\
\hline
\end{tabular}

Blood samples of Bmal1-KO and WT mice were activated with $0.5 \mathrm{pM}$ TF and $16.7 \mathrm{mM} \mathrm{CaCl}$. SD, standard deviation; ETP, endogenous thrombin potential; TTP, time-to-peak; VI, velocity index; KO, n=7; WT, $n=5$. 


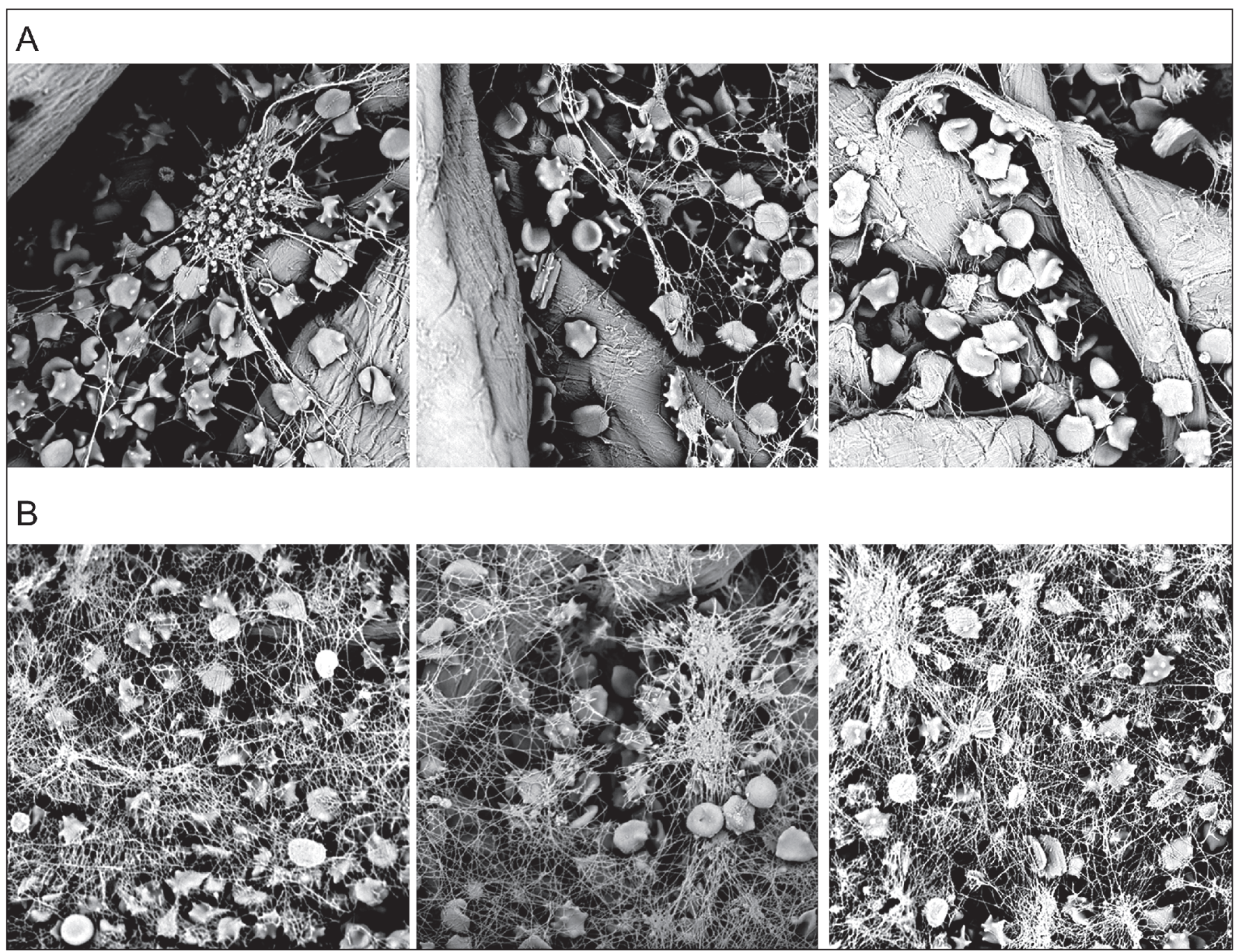

Figure 2: Representative SEM pictures of the fibrin network of Bmal1-KO and WT mice. TG was activated as described in Figure 1. After fixation SEM pictures were taken of the clots of Bmal1-WT (A) and KO-mice (B) of which three representative pictures are shown. Magnification was 5000x.

TG tests have been reported for platelet-poor and platelet-rich murine plasma. However, a major drawback of these assays is the requirement of relatively large amounts of plasma implying that the animal has to be sacrificed. In addition, under the conventional CAT conditions, mouse plasma appears to be highly reactive hampering reliable TG measurements $(1,4)$. These problems were solved by diluting the plasma samples. However, dilution of plasma dramatically distorts the balance between pro- and anticoagulant activity of the sample (11). Our assay proved to be reproducible and requires only a small amount of blood sample $(60 \mu \mathrm{l}$ per assay) and enables us to perform TG in blood collected at different time points from the same mouse. Moreover, the usage of whole blood eliminates the need to separate the analyte with a centrifugation step thereby reducing the number of pre-analytical variables and the experimental errors. Finally, measuring TG in the presence of blood cells might bring the assay closer to physiology. It is advised to use a low TF concentration $(0.5 \mathrm{pM})$ to keep the assay sensitive for the coagulations factors of the intrinsic coagu- lation pathway and to prevent clotting before the measurement is actually started.

As proof-of-principle we measured TG in the Bmall clock gene KO mice, which display symptoms of premature aging (21-23). These KO mice exhibit imbalances in the haemostatic mechanism, i.e. higher plasma levels of procoagulant factors VII, VIII, fibrinogen and raised platelet count on the one hand and decreased endothelial anticoagulants (thrombomodulin and protein $\mathrm{C}$ receptor) on the other hand. It was concluded that, with aging, progressive endothelial dysfunction, rising platelet counts, and high factor VII further enhance thrombogenicity and provoke priapism (23). In this paper we showed that Bmall-KO mice have a higher TG and fibrin formation compared to their Bmal1-WT littermates. This is confirming the results of Wolberg et al. who established that the fibrin formation is dependent on the thrombin concentration. A low thrombin concentration leads to a loosely woven fiber network with thick fibrin fibres, whereas high thrombin concentrations lead to a compact, dense network of thin fibrin fibres 


\section{What is known about this topic?}

- Studies have shown that hypo- and hypercoagulable conditions can be detected by measuring thrombin generation with the Calibrated Automated Thrombogram (CAT) assay in plasma.

- We developed a CAT-based assay (WB-CAT) able of measuring thrombin generation in whole blood.

- Bmal1-KO mice have a prothrombotic phenotype, although coagulation clotting tests reveal opposite results, as the aPTT is prolonged, while the PT is shortened.

\section{What does this paper add?}

- We showed that the WB-CAT assay is also feasible and reproducible in whole blood of mice. The advantage of this assay is that only very small amounts of blood are needed, so more conditions can be tested (e.g. different coagulation triggers and concentrations). The number of mice needed to conduct a study will decrease since blood samples can be taken repeatedly in time from the same mouse.

- As a proof of principle we looked at thrombin generation in Bmal1-KO mice and we could demonstrate with our WB-CAT assay a higher ETP and Peak height in these mice compared to their wild-type littermates.

(24-26). We also confirmed a higher platelet count in Bmal1-KO mice compared to WT mice of the same age. However, earlier studies from our group demonstrated that the whole blood platelet count does not contribute to the extent of TG in whole blood (17). Additionally, we established a higher red blood cell count in KO compared to WT mice. Based on our previous study it is not likely that an increased haematocrit affects TG in our assay (17). This is in contrast to the findings of Whelihan et al. who did find a haematocrit-dependent TG in mixtures containing only plasma and red blood cells (27-29). However, our experimental conditions were completely different (lower TF concentration; creation of a thin layer of blood by means of a porous matrix) which may provide an explanation for the observed differences.

The present findings of our study showed that our whole blood thrombin generation assay is also applicable on mouse blood and has a good reproducibility. As a proof-of-principle we have shown that the whole blood TG assay is capable of detecting a prothrombotic phenotype in Bmall-KO mice.

\section{Conflicts of interest}

None declared.

\section{References}

1. Dargaud Y, Spronk HM, Leenders P, et al. Monitoring platelet dependent thrombin generation in mice. Thromb Res 2010; 126: 436-441.

2. Hogan KA, Weiler H, Lord ST. Mouse models in coagulation. Thromb Haemost 2002; 87: 563-574.
3. Mackman N. Mouse models in haemostasis and thrombosis. Thromb Haemost 2004; 92: 440-443.

4. Tchaikovski SN, BJ VANV, Rosing J, et al. Development of a calibrated automated thrombography based thrombin generation test in mouse plasma. J Thromb Haemost 2007; 5: 2079-2086.

5. Tsakiris DA, Scudder L, Hodivala-Dilke K, et al. Haemostasis in the mouse (Mus musculus): a review. Thromb Haemost 1999; 81: 177-188.

6. Bunker JP, Goldstein R. Coagulation during hypothermia in man. Proc Soc Exp Biol Med 1958; 97: 199-202.

7. Martini WZ, Cortez DS, Dubick MA, et al. Thrombelastography is better than PT, aPTT, and activated clotting time in detecting clinically relevant clotting abnormalities after hypothermia, haemorrhagic shock and resuscitation in pigs. J Trauma 2008; 65: 535-543.

8. Reed RL, 2nd, Johnson TD, Hudson JD, et al. The disparity between hypothermic coagulopathy and clotting studies. J Trauma 1992; 33: 465-470.

9. Rohrer MJ, Natale AM. Effect of hypothermia on the coagulation cascade. Crit Care Med 1992; 20: 1402-1405.

10. De Smedt E, Al Dieri R, Spronk HM, et al. The technique of measuring thrombin generation with fluorogenic substrates: 1 . Necessity of adequate calibration. Thromb Haemost 2008; 100: 343-349.

11. De Smedt E, Wagenvoord R, Coen Hemker H. The technique of measuring thrombin generation with fluorogenic substrates: 3 . The effects of sample dilution. Thromb Haemost 2009; 101: 165-170.

12. Hemker HC, Al Dieri R, De Smedt E, et al. Thrombin generation, a function test of the haemostatic-thrombotic system. Thromb Haemost 2006; 96: 553-561.

13. Hemker HC, Giesen P, Al Dieri R, et al. Calibrated automated thrombin generation measurement in clotting plasma. Pathophysiol Haemost Thromb 2003; 33: 4-15.

14. Hemker HC, Giesen P, AlDieri R, et al. The calibrated automated thrombogram (CAT): a universal routine test for hyper- and hypocoagulability. Pathophysiol Haemost Thromb 2002; 32: 249-253.

15. Al Dieri R, Hemker CH. Thrombin generation in whole blood. Br J Haematol 2008; 141 : 895; author reply 896-897.

16. Tappenden KA, Gallimore MJ, Evans G, et al. Thrombin generation: a comparison of assays using platelet-poor and -rich plasma and whole blood samples from healthy controls and patients with a history of venous thromboembolism. Br J Haematol 2007; 139: 106-112.

17. Ninivaggi M, Apitz-Castro R, Dargaud Y, et al. Whole-blood thrombin generation monitored with a calibrated automated thrombogram-based assay. Clin Chem 2012; 58: 1252-1259.

18. Tripodi A. The long-awaited whole-blood thrombin generation test. Clin Chem 2012; 58: 1173-1175.

19. Hemmeryckx B, Himmelreich U, Hoylaerts MF, et al. Impact of clock gene Bmall deficiency on nutritionally induced obesity in mice. Obesity 2011; 19: 659-661.

20. Kondratov RV, Kondratova AA, Gorbacheva VY, et al. Early aging and age-related pathologies in mice deficient in BMAL1, the core componentof the circadian clock. Genes Dev 2006; 20: 1868-1873.

21. Somanath PR, Podrez EA, Chen J, et al. Deficiency in core circadian protein Bmall is associated with a prothrombotic and vascular phenotype. J Cell Physiol 2011; 226: 132-140.

22. Hemmeryckx B, Hoylaerts MF, Lijnen HR. Effect of premature aging on murine adipose tissue. Exp Gerontol 2012; 47: 256-262.

23. Hemmeryckx B, Van Hove CE, Fransen P, et al. Progression of the prothrombotic state in aging Bmall-deficient mice. Arterioscler Thromb Vasc Biol 2011; 31: 2552-2559.

24. Wolberg AS. Thrombin generation and fibrin clot structure. Blood Rev 2007; 21: 131-142.

25. Wolberg AS, Campbell RA. Thrombin generation, fibrin clot formation and haemostasis. Transfus Apher Sci 2008; 38: 15-23.

26. Wolberg AS, Monroe DM, Roberts HR, et al. Elevated prothrombin results in clots with an altered fiber structure: a possible mechanism of the increased thrombotic risk. Blood 2003; 101: 3008-3013.

27. Whelihan MF, Mann KG. The role of the red cell membrane in thrombin generation. Thromb Res 2013; 131: 377-382.

28. Whelihan MF, Mooberry MJ, Zachary V, et al. The contribution of red blood cells to thrombin generation in sickle cell disease: meizothrombin generation on sickled red blood cells. J Thromb Haemost 2013; 11: 2187-2189.

29. Whelihan MF, Zachary V, Orfeo T, et al. Prothrombin activation in blood coagulation: the erythrocyte contribution to thrombin generation. Blood 2012; 120: $3837-3845$. 